Article

\title{
Improvement of Postharvest Quality of Asian Pear Fruits by Foliar Application of Boron and Calcium
}

\author{
Kobra Khalaj, Nima Ahmadi * and Mohammad Kazem Souri \\ Department of Horticultural Sciences, Tarbiat Modares University, Tehran 336-14115, Iran; \\ kobra.khalaj@gmail.com (K.K.); mk.souri@modares.ac.ir (M.K.S.) \\ * Correspondence: ahmadin@modares.ac.ir; Tel.: +98-21-4829-2088; Fax: +98-21-4829-2200 \\ Academic Editors: Varit Srilaong, Mantana Buanong, Chalermchai Wongs-Aree, Sirichai Kanlayanarat and \\ Douglas D. Archbold \\ Received: 4 December 2015; Accepted: 9 November 2016; Published: 30 December 2016
}

\begin{abstract}
The aim of this study was to evaluate the effects of foliar application of boron and calcium on postharvest storage characteristics of Asian pear (Pyrus pyrifolia) fruit. This experiment was carried out in the experimental orchard of Asian pear at Tarbiat Modares University, Tehran, Iran. The treatments were two concentrations of boric acid $(0 \%$ and $0.5 \%)$ and three concentrations of calcium chloride $(0 \%, 0.5 \%$, and $0.7 \%)$ which were sprayed on trees during the growing season. The data showed that foliar application of these two elements resulted in improvement in physicochemical characteristics of the pear fruit, particularly fruit firmness and polyphenol oxidase activity. At harvest, fruit firmness and total soluble solids (TSS) were significantly improved by B and Ca application, compared to control fruit. Although fruit firmness decreased during 3 months of cold storage, fruit which received higher rates of $\mathrm{Ca}$ and $\mathrm{B}$ retained more firmness. During the storage period, total phenolic content was significantly reduced in control fruit compared to fruit which were sprayed with Ca and/or B. The highest level of polyphenol oxidase activity was in B and Ca sprayed fruit and the lowest was in control fruit. In general, foliar application of $\mathrm{Ca}$ and $\mathrm{B}$ resulted in improvement of postharvest characteristics of Asian pear fruit and reduced internal browning symptoms. Thus, application of $\mathrm{Ca}$ and $\mathrm{B}$ could be recommended as treatments for increasing postharvest life of Asian pear in similar semi-arid climates.
\end{abstract}

Keywords: boric acid; calcium chloride; foliar spray; internal browning; total soluble solids

\section{Introduction}

Asian pear (Pyrus pyrifolia), originating from the eastern part of Asia, has been cultivated for centuries. Due to the high quality of the fruit, cultivation and consumption of Asian pear fruit is increasing around the world [1]. The nutrient balance is the main factor that plays a role in postharvest quality of Asian pear fruit.

However, nutrients deficiency disorders are very common in many horticultural crops, particularly under arid and calcareous soil conditions. These disorders play important roles in quality and therefore in marketability of the crops. Calcium and boron are key elements in maintaining the quality and shelf life of fruits, particularly apple and pear. Both elements generally have similar uptake, translocation and correlated physiological roles. Cell strength, cell wall thickness and tissue firmness are highly dependent upon adequate amounts of calcium, mainly forming pectin in the middle lamella [2]. Optimum levels of calcium application have led to better stability of cell membranes and cell walls, and consequently resulted in increasing fruit quality [3]. Boron is another important element in quality parameters of fruits, in particular in pome fruit such as pear. Boron participates in many physiological reactions, particularly cell wall formation and metabolism of sugars and phenolic 
compounds. It helps maintain cell membrane structures integrity, and is also considered an antioxidant that prevents fruit internal browning [4].

So, the aim of this study was to evaluate the foliar application of calcium and boron on quality characteristics of Asian pear in fruit under the semi-arid climatic conditions of Tehran, Iran.

\section{Experimental Section}

\subsection{Plant Materials}

This study was conducted during 2010 and 2011 in an Asian pear orchard located at the Faculty of Agriculture, Tarbiat Modares University, in Tehran, Iran. The early Asian pear cultivar " $\mathrm{KS}_{10}$ " was used. The effect of foliar applications of boric acid $(0 \%, 0.5 \%)$ and calcium chloride $(0 \%, 0.5 \%$, and $0.7 \%$ ) were evaluated on harvest and postharvest storage quality. Trees were sprayed starting 20 days after full bloom three times with boric acid and/or six times with calcium chloride solutions at 2-week intervals (Table 1) in a factorial design within randomized complete blocks, three replications of each treatment combination, one replication (one tree) per block. Fruit were harvested approximately 90 days after full bloom, and held in cold storage at $2{ }^{\circ} \mathrm{C}$ and $85 \%$ relative humidity for 3 months. Fruit from each treatment were immediately sliced at harvest or after cold storage and frozen in liquid nitrogen, and then stored at $-80^{\circ} \mathrm{C}$ for further use.

Table 1. Different treatments and their abbreviations used in this experiment.

\begin{tabular}{ccc}
\hline Treatment & Calcium Chloride (\%) & Boric Acid (\%) \\
\hline c0b0 & 0 & 0 \\
c0b1 & 0 & 0.5 \\
c1b0 & 0.5 & 0 \\
c1b1 & 0.5 & 0.5 \\
c2b0 & 0.7 & 0 \\
c2b1 & 0.7 & 0.5 \\
\hline
\end{tabular}

\subsection{Physicochemical Quality Characteristics}

Physicochemical quality characteristics of fruit at harvest and after three months of cold storage were characterized. The fruit length and diameter were determined using digital calipers, and weight loss during cold storage was measured by weighing each fruit individually with a precision digital balance at the beginning and end of storage. After cutting the fruit into small pieces, they were dried at $70{ }^{\circ} \mathrm{C}$ in an oven to measure fruit dry weight. Fruit firmness and total soluble solids were evaluated using a portable penetrometer and refractometer, respectively. Titratable acidity was determined by titration of fruit juice by adding $0.1 \mathrm{~N} \mathrm{NaOH}$ solution to reach $\mathrm{pH}$ of 8.3 .

\subsection{The Total Phenol Content}

The total phenol content of fruit at harvest and three months after storage was determined by the Folin-Ciocalteu method [5]. To prepare the sample for total phenol quantification, frozen pieces of fruit were ground to a fine powder using a mortar and pestle cooled by liquid nitrogen during grinding. For quantification of total phenol content, $6 \mathrm{~mL}$ of $80 \%$ methanol was added to $1 \mathrm{~g}$ of powdered sample. Then samples were centrifuged at $14,000 \mathrm{rpm}$ for $20 \mathrm{~min}$ at $4{ }^{\circ} \mathrm{C}$. Extract $(20 \mu \mathrm{L})$ was added to $1.58 \mathrm{~mL}$ of distilled water containing $100 \mu \mathrm{L}$ Folin-Ciocalteu reagent. After $8 \mathrm{~min}, 300 \mu \mathrm{L}$ of $20 \%(w / v)$ sodium carbonate was added to the sample and placed $2 \mathrm{~h}$ at room temperature in darkness. The absorption of the sample was measured with a spectrophotometer at $765 \mathrm{~nm}$. The results were calculated based on using garlic acid as a standard and are expressed as $\mathrm{mg}$ garlic acid per $\mathrm{g}$ fresh weight of fruit. 


\subsection{Measuring the Activity of Polyphenol Oxidase Enzyme}

For measuring the activity of polyphenol oxidase enzyme activity after 3 months of storage, $200 \mathrm{mg}$ of fruit tissue powder was mixed with $3 \mathrm{~mL}$ sodium phosphate buffer $\left(25 \mathrm{mM}, \mathrm{pH}\right.$ 6.8) at $4{ }^{\circ} \mathrm{C}$, and the homogenate was centrifuged for $15 \mathrm{~min}$ at $4{ }^{\circ} \mathrm{C}$. The supernatant was used for measurement of enzyme activity. Activity of polyphenol oxidase in the supernatant was measured according to Ghanati et al. [6] with minor changes. Sodium phosphate buffer (50 mM, pH 6.8) was used. Methyl catechol $(0.15 \mathrm{M})$ was used as substrate. The reaction mixture contained $2 \mathrm{~mL}$ sodium phosphate buffer (50 mM, pH 6.8), $600 \mu \mathrm{L}$ methyl catechol $(0.15 \mathrm{M})$, and $400 \mu \mathrm{L}$ enzyme extract. Changes in the oxidation of catechol were monitored at $410 \mathrm{~nm}$ for $1 \mathrm{~min}$. Protein content of the supernatant was measured using the Bradford assay [7]. Polyphenol oxidase enzyme activity was determined as change in absorption at $410 \mathrm{~nm}$ for $1 \mathrm{~min}$ per $\mathrm{mg}$ protein.

\subsection{Statistical Analysis}

Statistical analysis was performed using SAS software (SAS Institute Inc., Cary, NC, USA) and diagrams were drawn using Excel software. Comparison of means was conducted using Duncan's New Multiple Range Test at $p=0.05$.

\section{Results}

Spray applications of boric acid and calcium chloride had no significant effect on fruit length and diameter at harvest and three months after storage (Tables 2 and 3). Fruit fresh weight was affected only by Ca spray. The highest fruit fresh weight $(54.72 \mathrm{~g})$ was with the $0.7 \%$ calcium treatment, and the lowest ( $40.77 \mathrm{~g}$ ) was the control (Figure 1). The fruit dry weight at harvest was only affected by the interaction of $\mathrm{Ca}$ and B. The highest fruit dry weight (17.48 g per $100 \mathrm{~g} \mathrm{FW}$ ) was with $7 \%$ Ca by $0.5 \% \mathrm{~B}$. After 3 months of storage, significant differences in fruit fresh weight were observed for the effect of $\mathrm{Ca}$, and for the interaction between $\mathrm{Ca}$ and $\mathrm{B}$ (Table 3). The highest fruit fresh weight $(56.63 \mathrm{~g})$ was at $0.7 \%$ Ca (Figure 2).

Table 2. Sums of squares in the analysis of variance for the effects of calcium and boron on physicochemical properties of pear fruit at harvest.

\begin{tabular}{ccccccccc}
\hline $\begin{array}{c}\text { Source of } \\
\text { Variation }\end{array}$ & df & $\begin{array}{c}\text { Fruit } \\
\text { Length }\end{array}$ & $\begin{array}{c}\text { Fruit } \\
\text { Diameter }\end{array}$ & $\begin{array}{c}\text { Fruit Fresh } \\
\text { Weight }\end{array}$ & $\begin{array}{c}\text { Fruit Dry } \\
\text { Weight }\end{array}$ & $\begin{array}{c}\text { Fruit } \\
\text { Firmness }\end{array}$ & $\begin{array}{c}\text { Total Soluble } \\
\text { Solids }\end{array}$ & $\begin{array}{c}\text { Titratable } \\
\text { Acidity }\end{array}$ \\
\hline Block & 2 & $9.25 \mathrm{~ns}^{\mathrm{z}}$ & $7.68 \mathrm{~ns}$ & $49.14 \mathrm{~ns}$ & $0.06 \mathrm{~ns}$ & $0.06 \mathrm{~ns}$ & $0.09 \mathrm{~ns}$ & $729.5 \mathrm{~ns}$ \\
Calcium & 2 & $22.31 \mathrm{~ns}$ & $30.09 \mathrm{~ns}$ & $293.9^{*}$ & $1.47 \mathrm{~ns}$ & $4.5^{* *}$ & $7.72^{* *}$ & $909.6 \mathrm{~ns}$ \\
Boron & 1 & $1.91 \mathrm{~ns}$ & $9.7 \mathrm{~ns}$ & $54.21 \mathrm{~ns}$ & $0.02 \mathrm{~ns}$ & $0.88^{* *}$ & $2.72^{* *}$ & $122.3 \mathrm{~ns}$ \\
Calcium $\times$ Boron & 2 & $1.48 \mathrm{~ns}$ & $2.8 \mathrm{~ns}$ & $22.43 \mathrm{~ns}$ & $2.99^{*}$ & $0.1 \mathrm{~ns}$ & $4.05^{* *}$ & $1029.1 \mathrm{~ns}$ \\
Error & 10 & 9.02 & 11.55 & 67.9 & 0.4 & 0.06 & 0.14 & 399.6 \\
$\mathrm{CV}(\%)^{\mathrm{z}}$ & - & 7.97 & 7.56 & 17.14 & 3.84 & 5.08 & 2.83 & 20.72 \\
\hline
\end{tabular}

$*, * *$ and ns indicate significant differences at $p \leq 0.05,0.01$, and no significant difference, respectively; ${ }^{z}$ Coefficient of variation.

Table 3. Sums of squares in the analysis of variance for the effects of calcium and boron on physicochemical properties of pear fruit after three months of cold storage.

\begin{tabular}{cccccccc}
\hline Source of Variation & df & $\begin{array}{c}\text { Fruit } \\
\text { Length }\end{array}$ & $\begin{array}{c}\text { Fruit } \\
\text { Diameter }\end{array}$ & $\begin{array}{c}\text { Fruit Fresh } \\
\text { Weight }\end{array}$ & $\begin{array}{c}\text { Fruit } \\
\text { Firmness }\end{array}$ & TSS & TA \\
\hline Block & 2 & $0.66 \mathrm{~ns}$ & $0.99 \mathrm{~ns}$ & $5.07 \mathrm{~ns}$ & $0.07 \mathrm{~ns}$ & $1.39^{*}$ & $1.93 \mathrm{~ns}$ \\
Calcium & 2 & $16.61 \mathrm{~ns}$ & $7.52 \mathrm{~ns}$ & $216.64^{* *}$ & $1.39 * *$ & $31.35^{* *}$ & $630.396 \mathrm{~ns}$ \\
Boron & 1 & $3.78 \mathrm{~ns}$ & $0.01 \mathrm{~ns}$ & $21.15 \mathrm{~ns}$ & $0.02 \mathrm{~ns}$ & $6.12^{* *}$ & $360.08 \mathrm{~ns}$ \\
Calcium $\times$ Boron & 2 & $3.59 \mathrm{~ns}$ & $0.65 \mathrm{~ns}$ & $112.80^{* *}$ & $0.02 \mathrm{~ns}$ & $12.12^{* *}$ & $1109.26^{*}$ \\
Error & 10 & 5.15 & 7.98 & 10.04 & 0.03 & 0.29 & 164.43 \\
$\mathrm{CV}(\%)^{\mathrm{z}}$ & - & 6.80 & 6.99 & 6.57 & 5.73 & 3.36 & 13.99 \\
\hline
\end{tabular}

$*^{* * *}$ and ns indicate significant differences at $p \leq 0.05,0.01$, and no significant difference, respectively;

${ }^{\mathrm{z}}$ Coefficient of variation. 


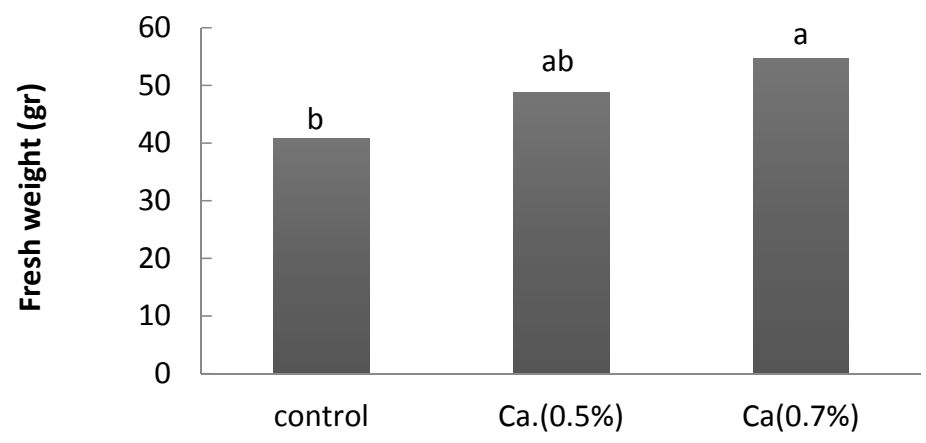

Figure 1. The effect of calcium (\%) on fruit fresh weight at harvest. Means with different letters were significantly different by Duncan's New Multiple Range Test at $p=0.05$.

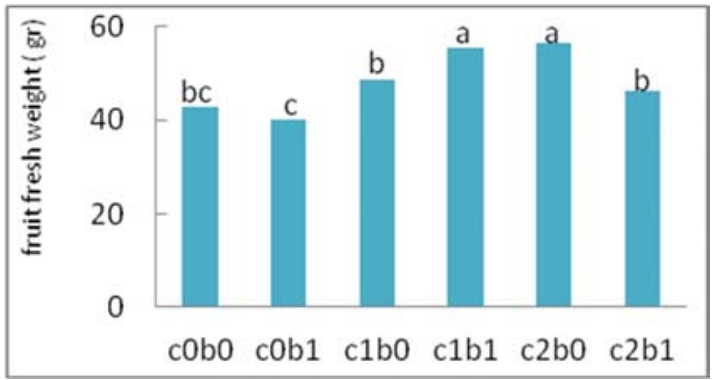

Figure 2. Interaction between calcium and boron on fruit fresh weight after three months of cold storage. See Table 1 for definitions of treatment abbreviations. Means with different letters were significantly different by Duncan's New Multiple Range Test at $p=0.05$.

Fruit firmness at harvest was affected by both $\mathrm{Ca}$ and $\mathrm{B}$, but not by their interaction (Table 2). The highest fruit firmness $\left(5.83 \mathrm{~kg} / \mathrm{cm}^{2}\right)$ was with $0.7 \% \mathrm{Ca}$, and the lowest firmness $\left(4.1 \mathrm{~kg} / \mathrm{cm}^{2}\right)$ was the control (Figure 3). Similarly, fruit firmness was significantly higher at $0.5 \% \mathrm{~B}\left(5.17 \mathrm{~kg} / \mathrm{cm}^{2}\right)$ compared to the control $\left(4.73 \mathrm{~kg} / \mathrm{cm}^{2}\right)$ (data not shown). Analysis of variance showed that after three months of cold storage, firmness was only affected by $\mathrm{Ca}$ (Table 3). The highest fruit firmness $\left(3.23 \mathrm{~kg} / \mathrm{cm}^{2}\right)$ was at $0.7 \% \mathrm{Ca}$, and the lowest $\left(2.3 \mathrm{~kg} / \mathrm{cm}^{2}\right)$ was the control (Figure 3).

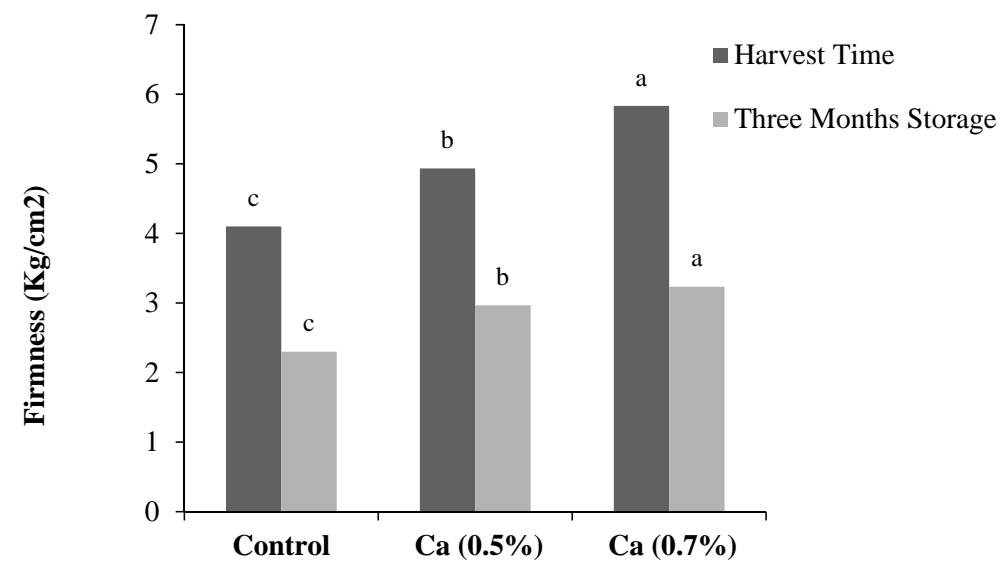

Figure 3. The effect of calcium (\%) on fruit firmness at harvest and after three months of cold storage. Means with different letters within harvest or storage time were significantly different by Duncan's New Multiple Range Test at $p=0.05$. 
Total soluble solids at harvest showed significant effects of $\mathrm{Ca}, \mathrm{B}$ and their interaction (Table 2). The highest TSS (16 ${ }^{\circ}$ Brix) was the control (Figure 4$)$. After 3 months of cold storage, TSS showed significant effects of $\mathrm{Ca}, \mathrm{B}$, and their interaction (Table 3). The highest TSS (20 $\left.{ }^{\circ} \mathrm{Brix}\right)$ was in control fruit (Figure 4). At harvest, there were no significant differences among treatments in TA values. However, after 3 months of storage, TA was significantly affected by the interaction of B and Ca (Table 3), as the highest was measured in the $0.7 \%$ Ca treatment.

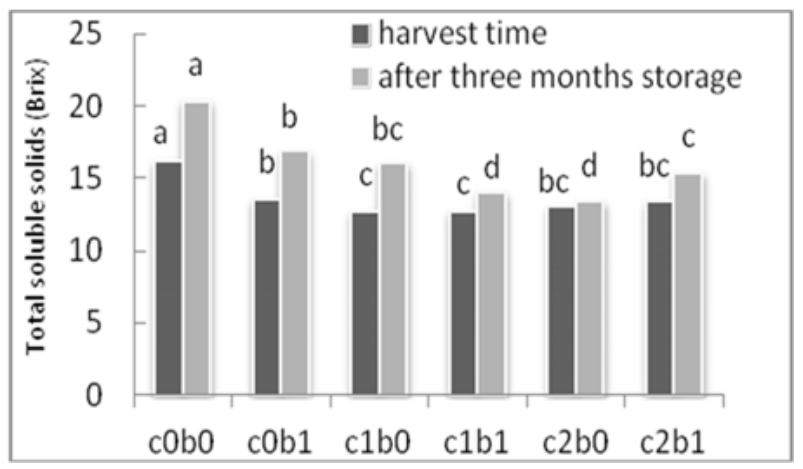

Figure 4. Interaction between calcium and boron on total soluble solids at harvest and after three months of cold storage. See Table 1 for definitions of treatment abbreviations. Means with different letters within harvest or storage time were significantly different by Duncan's New Multiple Range Test at $p=0.05$.

At harvest, control fruit had the highest total phenol content, while application of $\mathrm{Ca}$ and $\mathrm{B}$ reduced total phenol content. Fruit treated with $0.7 \% \mathrm{Ca}$ and $0.5 \% \mathrm{~B}\left(\mathrm{c}_{2} \mathrm{~b}_{1}\right)$ showed the lowest phenol content (Figure 5). In addition, total phenol content showed a significant reduction during cold storage, and the reduction in the control samples was more than in B and Ca treated fruit. Control fruit showed the lowest total phenol after 3 months of cold storage. For fruit receiving $0.7 \% \mathrm{Ca}$ and $0.5 \% \mathrm{~B}$ $\left(c_{2} b_{1}\right)$ treatment, the total phenol was maintained (Figure 5). Ca application reduced the activity of polyphenol oxidase at 3 months (Figure 6). Thus, after storage, PPO activity was highest in control fruit, which was accompanied by a reduction in phenolic content. Thus, treating fruit with $\mathrm{B}$ and $\mathrm{Ca}$ during the growing season reduced the activity of PPO at the end of the storage period (Figure 6).

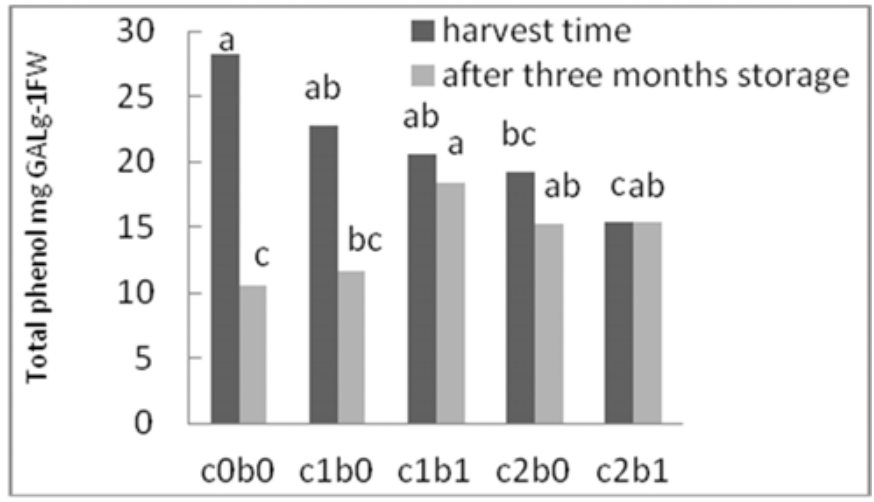

Figure 5. Total phenol at harvest and after three months of cold storage. See Table 1 for definitions of treatment abbreviations. Means with different letters within harvest or storage time were significantly different by Duncan's New Multiple Range Test at $p=0.05$. 


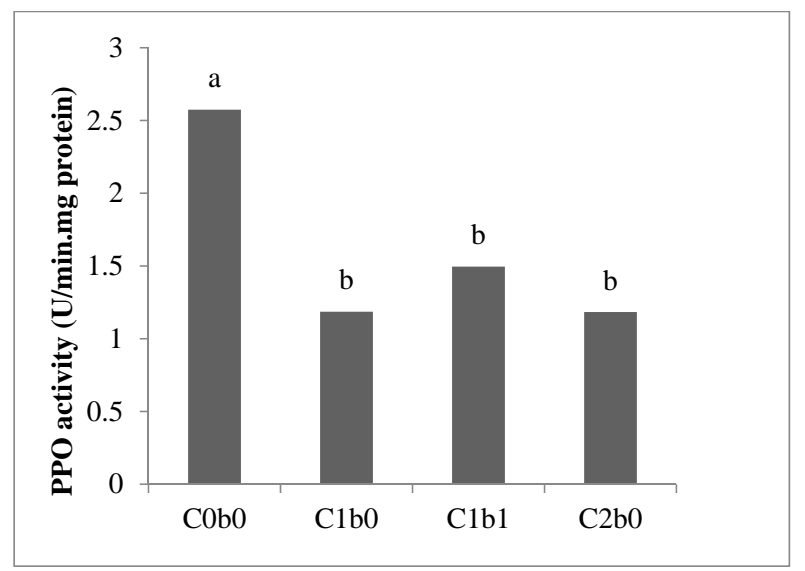

Figure 6. Activity of polyphenol oxidase after three months of cold storage. See Table 1 for definitions of treatment abbreviations. Means with different letters were significantly different by Duncan's New Multiple Range Test at $p=0.05$.

\section{Discussion}

In this study, fresh weight was increased by $\mathrm{Ca}$, and dry weight of fruit was increased by $\mathrm{Ca} \times \mathrm{B}$ applications. Increasing cell wall and pectin amounts probably were involved in these responses. Other studies also reported improvement of fruit weight with foliar sprays of $\mathrm{Ca}$ and $\mathrm{B}$ [8,9]. Fruit firmness was also significantly improved by $\mathrm{Ca}$ and B sprays. Increasing pectin levels in the cell wall also probably played a role in this regard [10]. Fruit firmness declined during storage. However, Ca application resulted in a higher fruit firmness compared to the control both at harvest as well as after 3 months of cold storage. Treatment of apple fruit two weeks before maturity with $8 \%$ calcium chloride has significantly increased fruit firmness [11]. Also, by application of $4 \%$ calcium chloride, Asian pear fruit firmness increased compared to a control [12]. In this study, Ca reduced fruit TSS, similar to results obtained by some others [13], although other research has had different results $[8,9,14]$. Betts and Bramlage [14] reported that in apple fruit, Ca did not affect TSS as application of Ca reduced respiratory rate and consequently degradation of starch to simple sugars, as well as total soluble solids. Total soluble solids increased during storage, probably due to conversion of starch to sugar. Titratable acidity of fruit decreased during storage. Previous reports indicated that acidity in pear and other fruits gradually increased until final fruit size, while it decreased during maturation, ripening and storage of apple [15]. Similar results were obtained in the present study. Other studies also reported reduction of organic acids during storage of Yali pear [16], although there are reports showing that acidity was not affected by $\mathrm{Ca}$ [11]. The role of calcium in cell wall strength is probably responsible for most quality-related properties of this element. Calcium was shown to reduce the production of phenolic compounds in fruit [17], and also increase the polysaccharides and non-alcohol-soluble solids in the fruit cell walls. It also maintained cell membrane stability $[3,18,19]$. The reduction in total phenolic levels in control fruit after three months of cold storage was likely due to the higher activity of polyphenol oxidase enzyme (Figure 6), resulting in oxidation of phenolic compounds and internal browning in fruit tissue (Figure 7). Generally, prevention of phenol oxidation by application of Ca and B has mainly been related to their effects on cell membrane integrity and membrane permeability [20,21]. Boron, on the other hand, facilitates the role of calcium in cell membrane and cell wall interactions. Nevertheless, both Ca and B have restricted transport within plants, in particular under semi-arid and calcareous soil conditions. Therefore, foliar sprays of these two nutrient elements several times during a growing season can improve $\mathrm{Ca}$ and $\mathrm{B}$ concentration in fruit tissues [21]. 


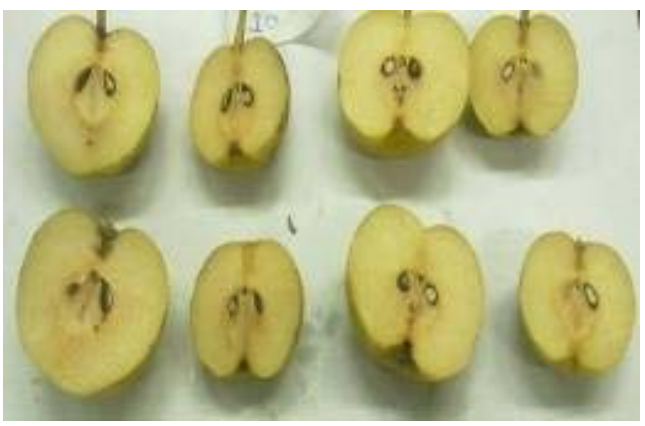

(a)

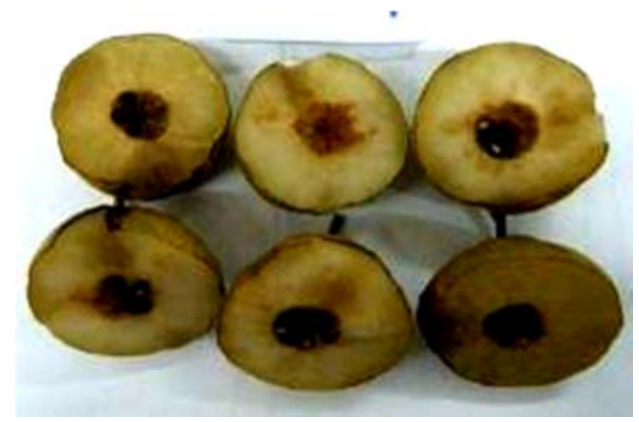

(b)

Figure 7. Internal browning after three months of cold storage $\left(2{ }^{\circ} \mathrm{C}, 85 \%\right.$ relative humidity). (a) $\mathrm{Ca}$ at $0.7 \%$; (b) Control.

\section{Conclusions}

In the present study, application of both $\mathrm{Ca}$ and $\mathrm{B}$ improved the physical and chemical characteristics of fruit compared to a control. Increasing fruit firmness and TSS due to Ca and B applications could have important implications, particularly in terms of fruit quality and storage life. Foliar sprays of both Ca and B reduced the activity of polyphenol oxidase enzyme, which is mainly responsible for internal browning of fruit. The role of calcium in cell wall strength was probably responsible for most quality-related properties of this element. So, using foliar applications of Ca and $B$ during the growing season of Asian pear trees is recommended for improving postharvest quality parameters of fruit in semi-arid regions.

Acknowledgments: We would like to thank Kazem Arzani, Department of Horticultural Sciences, Tarbiat Modares University, for providing the plant materials and samples used in this research.

Author Contributions: Nima Ahmadi and Mohammad Kazem Souri designed the study. Running experiment, sampling and evaluation of characteristics were performed by Kobra Khalaj through supervision and advising of Nima Ahmadi and Mohammad Kazem Souri respectively, by providing necessary suggestions during the research. The data analysis and interpretation was performed by Kobra Khalaj, Nima Ahmadi and Mohammad Kazem Souri. The manuscript was prepared by Kobra Khalaj, Nima Ahmadi and Mohammad Kazem Souri. All authors reviewed and approved of the final manuscript.

Conflicts of Interest: The authors declare no conflict of interest.

\section{References}

1. Chen, J.; Wang, Z.; Wu, J.; Wang, Q.; Hu, X. Chemical compositional characterization of eight pear cultivars. J. Food Chem. 2007, 104, 268-275. [CrossRef]

2. Subburamu, K.; Singaravelu, M.; Nazar, A.; Irulappan, I. Pre-harvest spray of calcium in grapes (Vitis vinifera). South Indian Hort. 1990, 5, 268-269.

3. Sharpels, R.O.; Johnson, D.S. The influence of calcium on senescence changes in apples. Ann. Appl. Biol. 1977, 85, 150-453.

4. Dzondo-Gadet, M.; Mayap-Nzietchueng, R.; Hess, K.; Nabet, P.; Belleville, F.; Dousset, B. Action of boron at the molecular level: Effects on transcription and translation in an acellular system. Biol. Trace Elem. Res. 2002, 85, 23-33. [CrossRef]

5. Singh, R.P.; Murthy, K.N.C.; Jayaprakasha, G.K. Studies on the antioxidant activity of pomegranate (Punica granatum) peel and seed extracts using in vitro models. J. Agric. Food Chem. 2002, 50, 81-86. [CrossRef] [PubMed]

6. Ghanati, F.; Morita, A.; Yokota, H. Induction of suberin and increase of lignin content by excess boron in tobacco cell. Soil Sci. Plant Nutr. 2002, 48, 357-364. [CrossRef]

7. Bradford, M. A rapid and sensitive method for the quantitation of protein utilizing the principle of protein-dye binding. Anal. Biochem. 1976, 72, 248-254. [CrossRef] 
8. Khoshgalb, H. The Effects of Calcium, Zinc and Boron on the Chemical Composition of Fruits, Postharvest Shelf Life and Reduce Symptoms of Internal Browning of Fruits of Two Varieties of Asian Pear (Pyrus serotina Rehd.) in Tehran Climate. Ph.D. Thesis, Faculty of Agriculture, Tarbiat Modarres University, Tehran, Iran. (In Persian)

9. Akl, A.M.; Eid, A.F.M.; Hegab, M.Y. Effect of urea, some micronutrients and growth-regulators foliar spray on the yield, fruit quality, and some vegetative characteristics of "Washington Navel" orange trees. Hort. Sci. 1995, 30, 774-780.

10. Veltman, R.H.; Sanders, M.G.; Persijn, S.T.; Peppelenbos, H.W.; Oosterhaven, J. Decreased ascorbic acid levels and brown core development in pears (Pyrus communis cv. "Conference"). Physiol. Plant. 1999, 107, 39-45. [CrossRef]

11. Conway, W.S.; Sams, C.E. Effect of postharvest calcium treatment on decay of Delicious apples. Plant Dis. 1982, 66, 402-403. [CrossRef]

12. Dhatt, A.S.; Mahajan, B.V.C.; Bhatt, A.R. Effect of pre and post-harvest calcium treatments on the storage life of Asian pear. ISHS Acta Hortic. 2005, 696, 497-501. [CrossRef]

13. Dolati Baneh, H.; Hacani, A.; Majidi, A.; Zomorrodi, S.; Hacani, G.; Malakoti, M.J. Effect of calcium chloride on foliar concentration and frequency characteristics of stiffness and a Lebanese Red apples stored in Urmia region. J. Agric. Sci. 2002, 12, 47-54. (In Persian)

14. Betts, H.A.; Bramlag, W.J. Uptake of calcium by apples from postharvest dips in calcium chloride solutions. J. Am. Soc. Hortic. Sci. 1979, 102, 785-788.

15. Ackerman, J.; Fischer, M.; Amado, R. Changes in sugars, acids, and amino acids during ripening and storage of apples (cv. Glockenapfel). J. Agric. Food Chem. 1992, 40, 1131-1134. [CrossRef]

16. Chen, J.L.; Yan, S.J.; Feng, Z.; Xiao, L.; Hu, X.S. Changes in the volatile compounds and chemical and physical properties of "YaLi" pear (Pyrus bertschneideri Rehd) during storage. Food Chem. 2006, 97, 248-255. [CrossRef]

17. Coseteng, M.Y.; Lee, C.Y. Changes in apple polyphenoloxidase and polyphenol concentrations in relation to degree of browning. J. Food Sci. 1987, 52, 985-989. [CrossRef]

18. Malakoti, M.J.; Tehrani, M.M. The Role of Micronutrients in Increasing Yield and Improving the Quality of Agricultural Products, 3rd ed.; Tarbiat Modares University: Tehran, Iran, 2001.

19. Dunn, J.L.; Able, A.J. Pre-harvest calcium effects on sensory quality and calcium mobility in strawberry fruit. Acta Hortic. 2006, 708, 307-312. [CrossRef]

20. Tomas-Barberan, F.A.; Gil, M.I.; Castaner, M.; Artes, F.; Saltveit, M.E. Effect of selected browning inhibitors on phenolic metabolism in stem tissue of harvested lettuce. J. Agric. Food Chem. 1997, 45, 583-589. [CrossRef]

21. Tohidloo, G.; Souri, M.K. Uptake and translocation of boron in two different tomato genotypes. Hortic. Environ. Biotechnol. 2009, 50, 487-491.

(C) 2016 by the authors; licensee MDPI, Basel, Switzerland. This article is an open access article distributed under the terms and conditions of the Creative Commons Attribution (CC-BY) license (http:/ / creativecommons.org/licenses/by/4.0/). 